\title{
National Constitutions and Human Rights Issues in Africa ${ }^{1}$
}

\author{
E. IKE UDOGU*
}

\begin{abstract}
Philosophers such as Socrates, Plato, Aristotle, Hobbes, Locke and Marx, in the European context, and Dubois, Cabral, Fanon, and Ake, in the African political situation investigated and worked on modalities for constructing "the good political life" for human beings in a society with some success in the Occident and limited outcome in Africa. In the latter, the postcolonial period was marked by political competition over the control of the apparatus of power, the problems of human rights and political legitimacy, inter alia. Indeed, provisions were made in the constitution intended to assuage some of these conflictive problems. One such measure was the respect for human rights. The purpose of this essay is to show, concisely, how African governments have not always implemented human rights instruments contained in their constitutions, and to suggest ways that they might, in order to further stability in the area.
\end{abstract}

\section{Introduction: Issues and Objectives}

Humankind's incessant quest for the freedom to pursue common objectives within an orderly polity explains in a way why regimes are tolerated even

\footnotetext{
${ }^{1}$ A variation of this paper was presented at the 19th annual conference of the Association of Third World Studies (ATWS) held in Savannah, Georgia, in 2001, and at the 20th annual conference of the ATWS held at the National University of Taiwan, Taipei, the Republic of China, in December 2002.

"Professor of Political Science, Francis Marion University, Florence, South Carolina, 29501-0547, USA; Email: eudogu@fmarion.edu
} 
when at times the actions of the custodians of power and government itself leave much to be desired. This is so in terms of state use of force to implement policies and to quell or silence the opposition. Within this context, too, the state as represented by the agents and agencies of government sometimes uses its power to suppress individual and group freedoms. The clash between individual/group interests and that of a regime oftentimes intensify human rights problems in many societies. Indeed, Africa is not immune from this problem. It is in light of this development that this disquisition seeks to address human rights issues in Africa under the following rubrics:

- Constitution and constitutionalism.

- Human rights: a brief overview.

- Abstracts on human rights provisions contained in the constitution of selected countries.

- Summary report on human rights practices in two African countries.

- Universal and cultural relativity debate on human rights: A concise analysis.

- Some recommendations for solving human rights issues in Africa, and

- Conclusion.

It is hoped that this study might help tackle human rights infractions in the continent - a condition that is necessary to create the enabling environment for politico-economic and socio-religious stability and a priori lead to "the good political life for all African citizens."

\section{Constitution and Constitutionalism}

The character, context and content of an African constitution derive, to some extent, from the interaction of the colonial powers and indigenous African leaders. In fact, it was at the Berlin Conference of 1884/5 that the European powers in a zigzag fashion mapped out the continent into their spheres of influence, and proceeded to govern their entities ad libitum. It goes without saying that at the end of colonialism, Britain, France, Portugal, and Belgium, mainly, contributed in one way or the other to the crafting of the constitution with which their former colonies where governed. Another issue, among others, that has also impacted on the content of an African constitution is religion.

Colonially, France's policies of assimilation and mission civilisatrice in Africa contributed to the texture of the constitution of some African states. For example, noted John M. Mbaku (1996, p. 41): "The first constitution of the ... former French colony of Cameroon was basically a copy of that of the French Fifth Republic despite the fact that the two countries differ significantly culturally, geographically, economically, socially, and in many 
other ways." As a matter of fact, the 1996 constitution of Cameroon has the Universal Declaration of Human Rights and the African Charter on Human and Peoples' Rights appended to Article 69, the last clause in this document. Indigenously, in the Nigerian case, the introduction of the Shari'a, an Islamic form of jurisprudence, to her constitutions, including the 1999 constitution, illustrates the extent to which strong religious beliefs could affect the character of a national constitution, too.

In spite of the above conjectures, however, the use of constitutions to delineate how a state is to be governed in order to check on the malfeasance of officials of a government is often promoted in most systems. Yet, many political actors seldom show enthusiasm in the enforcement of human rights principles contained in national constitutions especially if such provisions are antinomic to their self/group interests. But what is a constitution? Jan-Erik Lane (1996, p. 5) contends that a constitution is "a compact document that comprises a number of articles about the State, laying down rules which State activities are supposed to follow. Whether these rules are obeyed or implemented is another matter." Jack C. Plano and Milton Greenberg (1985, p. 33) defined a constitution as "a fundamental or 'organic' law that establishes the frame-work of government of a state, assigns the powers and duties of governmental agencies, and establishes the relationship between the people and their government." Elsewhere, it is defined as a document that outlines the manner and nature of interactions between the government and the people. It also establishes the institutions and structures with which to govern - in particular, a polity (Udogu 1997b, p. 2).

The content of a constitution can be complex or simple given the sociocultural specificity of the milieu in which the legal document is crafted. Within this context, arguably, it might be difficult to write about a specific theory of constitutions. Thus, "what there is is a set of ideas, concepts and models drawn from various disciplines that refer to constitutions, either the constitutions of the many countries in the world or to some ideal constitution ... (Lane 1996, p. 1)." Although constitutional theory hardly possesses a core of established dogmas, it remains a subject of major inquiry and discourse especially since some aspects of constitutional theory deal with the complexities of how countries are actually governed.

However, there is a paradox arising from the whole matter of constitutions because although they might be indispensable for the peaceful governance of a society, theoretically speaking, they can also be problematic in their operation especially in developing countries. The interpretative contradictions in the constitutional question in many African countries flow from the assumption that many constitutions "lack" legitimacy in part because they are seldom seen by the citizens of these countries. Sociologically, 
too, most African families are more concerned with addressing individual problems at the work place, home and extended family system to be bothered by human rights issues enshrined in national constitutions. Moreover, a large number of the population in the society cannot read or write, let alone comprehend some of the complex and problematic legal lingo of the constitution. Thus, a majority of the citizens in African nation-states are governed with a document that is not easily accessible to the populace. And, what is more? The intricate and elite interest-driven constitution is seldom approved in a national referendum, or by other means of legitimation, in order to further the document's national appreciation and acceptance (Ihonvbere, 2000). Indeed, as Donald S. Lutz (1994, pp. 355-357) has noted:

In a sense, the entire idea of a constitution rests on an assumption of human fallibility, since, if humans were angels, there would be no need to erect, direct, and limit government through a constitution... A constitution, [therefore], was viewed as a means not merely to make collective decisions in the most efficient way possible but to make the best possible decisions in pursuit of the common good under a condition of popular sovereignty... Popular sovereignty implies that all constitutional matters should be based upon some form of popular consent, which in turn implies a formal, public process...

The issues of a constitution and how it is promulgated in many African countries are complicated by the "absence" of constitutionalism - a condition generally exacerbated by the actions of some of the guardians of power, who attempt to manipulate the legal document by the use of extra-juridical means. In this practice, the power-brokers sometimes ignore the tenets of the constitutional document because provisions in it impinge upon their real or putative interests. Moreover, in the authoritarian systems that are commonplace in much of Africa, some leaders oftentimes behave as though they have regal or "deistic" immunity over provisions of the national constitution - a tradition analogous to that of Louis XIV and his dictum: L'etat c'est moi. What, then, is constitutionalism that is generally accentuated and promoted by students of constitution, especially in the quest to further stability and good governance? Constitutionalism is,

the political doctrine that claims that political authority should be bound by institutions that restrict the exercise of power. Such institutions offer rules that bind both the persons in authority as well as the organs or bodies that exercise political power. Human rights are one central component [or appurtenance] of constitutionalism; another essential element is the separation of powers in government. (Lane 1996, p. 2)

William G. Andrews (1963, p. 26) noted that: "constitutionalism, deriving its authority from the belief in transcendent principles of justice and right, 
controls government by limiting its authority and establishing regular procedures for its operation." "Carl Friedrich defined constitutionalism as "an institutionalized system of effective regularized restraints on governmental action ... such restraints may be extra-legal as well as legal, as, for example, regular and effective criticism and possible opposition by pelitical parties, the press, or pressure groups" (see Paul Sigmund 1979, p. 34; Udogu 1997a, pp. 5-6).

The centrality of this essay is neither based on the theory of constitution nor constitutionalism although the characteristics of these concepts interlace within the main edifice of this thesis. Germane to this study, however, is the examination of some African constitutions, as they relate to the issues of human rights. Further, this essay would illustrate how these legal documents have not always been seriously and judiciously applied to the promotion of the respect for human rights in the continent - the outcome of which tends to promote politico-social and religio-economic instability in the region.

\section{Human Rights: A Brief Overview}

Theoretically, human rights issues have become global in character. Indeed, for better or worse, it is instructive that at the beginning of this millennium that "powerful" nations have asserted that they were prepared to go to war to protect the human rights of those whose rights are claimed to be violated. In fact, one of the claimed reasons given for the United States-led war on Iraq with the support of Great Britain and Spain, was mainly the violation of the human rights of the Iraqis, by Saddam Hussein and his regime.

But in many polities, especially in the African context, human rights issues are generally of concern to members of the informed public and not to the masses whose comprehension of the questions of human rights are very limited or nonexistent at all. Generally, it is their rights that are often flouted by the agents of the government. It goes without saying that in order to further political stability and peaceful coexistence, in a continent that is rift with ethno-religious clashes, it will require mutual trust that is based in part on the respect of the human rights of all citizens (Udogu 2001, pp. 89-90).

The significance of the issues of human rights, at least, during the last 50 years has been of great concern to the international community. In 1998, several international conferences and symposia were held to mark the 50th anniversary of the epochal signing of the Universal Declaration of Human Rights in 1948. Indeed, there were assemblies and conferences held at the United Nations, Universities and other fora. Relevant to the agendas of these important meetings were strategies for promoting individual as 
well as group rights globally. The convocations also tackled some human rights appurtenances, as, for example, the rule of law, freedom of the press and so on. The assumption is that the respect for the rule of law and freedom of expression and the press can improve human rights issues and promote stability and development. Furthermore, Human Development Report 2000 devoted over half of the volume to addressing human rights issues worldwide. This concern, one could contend, points to the perplexing situation that although members of the United Nations might have come a long way in improving the conditions of human rights in their various countries, there is still much work to be done to tackle human rights infractions in many polities. And, the search for improvement in the implementation of the respect for human rights in Africa is probably greater now than ever before due to the current social, religious, economic, ethnic and political malaise throughout the area (Udogu 2000, pp. 35-38).

Indeed, within the framework of the Universal Declaration of Human Rights, General Assembly Resolution 217A of December 10, 1948 affirmed that:

Whereas recognition of the inherent dignity and of the equal and inalienable rights of all members of the human family is the foundation of freedom, justice and peace in the world...

Whereas the peoples of the United Nations have in the Charter reaffirmed their faith in fundamental human rights, in the dignity and worth of the human person and the equal rights of men and women and have determined to promote social progress and better standards of life in larger freedoms ... [hereby]:

Proclaims this Universal Declaration of Human Rights as a common standard of achievement for all peoples and all nations, to the end that every individual and every organ of society, keeping this Declaration constantly in mind, shall strive by teaching and education to promote respect for these rights and freedoms and by progressive measures, national and international, to secure their universal and effective recognition and observance, both among the peoples of Member states themselves and among the peoples of territories under their jurisdiction... (cited in Donnelly 1998, pp. 165-169)

Arguably, the above resolution, in a way, subsumes a number of provisions in the 1948 Declaration. In any case, a concise summary of the intents of the Universal Declaration of Human Rights were further explained in the following context:

The right to life, liberty, and security of person; the right to freedom of thought, speech, and communication of information and ideas; freedom of assembly and religion; the right to government through free elections; the 
right to free movement within the state and free exit from it; the right to asylum in another state; the right to nationality; freedom from arbitrary arrest and interference with the privacy of home and family; and the prohibition of slavery and torture; ... the right to work, to protection from unemployment, and to join trade unions; the right to a standard of living adequate for health and well-being; the right to education; and the right to rest and leisure. (Couloumbis and Wolfe, 1990, p. 291)

It is possible that the inspiring dogmas contained in the above proclamation may have galvanized into action students of human rights and activists in support of human rights practices universally. This is particularly relevant since the enforcement of the provisions of human rights in national/international compacts could mollify conflicts throughout the world. Nevertheless, in the African context, the presence of Africa Human Rights Watch, and other human rights NGOs monitoring the implementation of the various human rights instruments in the continent, suggests that there exist contradictions between theoretical idealism and political realism in the area regarding the infractions of human rights.

However, germane to this study is an examination of appropriate measures in the constitutions of a number of African countries that address the questions of human rights, and a concise investigation of the extent to which the records of these nation-states reveal a shortcoming or malfeasance on human rights practices.

The proceeding section, which is made up of six constructed illustrations (Table 1), is intended to highlight some of the human rights dimensions in the constitutions of subjectively selected African states. At best, they are abridgments.

Illustrations 1-6 provide a very brief synopsis of the extent to which the issues of human rights are addressed in the constitutions of a selection of African countries. This subjective approach to my choice of countries for analysis was borne out, or informed by, the reality that it might be extremely difficult to study human rights infractions in over 50 countries in the continent. Be that as it may, there are different levels of concern expressed on human rights questions in each constitution examined. Overall, though, it seems as if human rights provisions are inculcated into the constitution with, ostensibly, some degree of commitment. But, a cursory examination of African constitutions reveals that most constitutions are relatively silent on women's rights. These "omissions" probably issue from the socio-cultural and religious character of African states in which women tend to be culturally marginalized. Although this trend is gradually changing in Africa (particularly sub-Saharan Africa) due to the politicization of women, and women's greater demand for their rights, the respect for human rights, as it concerns women, is still problematic in most. This is 
Table 1

Abstracts on Human Rights Provisions Contained in the Constitutions of Selected African Countries by Regions

\section{Illustration 1 - West Africa}

Nigeria:

Article 33:

Article 34(1):

Article 35(1):

Article 36(1):

Article 39(1):
Chapter 4 of the 1999 Constitution (Articles 33-39).

Every person has a right to life, and no one shall be deprived intentionally of his [or her] life...

Every individual is entitled to respect for the dignity of his person, and accordingly (a) no person shall be subject to torture or to inhuman or degrading treatment...

Every person shall be entitled to his personal liberty and no person shall be deprived of such liberty [within the context of the existing law].

In the determination of a [person's] civil rights and obligations, including any question of determination by or against any government or authority, a person shall be entitled to a fair hearing within a reasonable time by a court or other tribunal established by law and constituted in such a manner as to secure its independence and impartiality...

Every person shall be entitled to freedom of expression, including freedom to hold opinions and to receive and impart ideas and information without interference...

\section{Illustration 2}

Kenya:

Article 70:

Article 74(1):

Article 78(1):

\section{East Africa}

Chapter V: Protection of Fundamental Rights and Freedoms of Individual.

Whereas every person in Kenya is entitled to the fundamental rights and freedoms of the individual, that is to say, the right, whatever his [or her] race, tribe, place of origin or residence or other local connection, political opinions, color, creed or sex, but subject to respect for the rights and freedoms of others and for the public interest, to each and all of the following, namely: (a) life, liberty, security of the person and the protection of the law; (b) freedom of conscience, of expression and of assembly and association; and (c) protection of the privacy of his [or her] home and other property and from deprivation of property without compensation...

No person shall be subject to torture or to inhuman or degrading punishment or other treatment...

Except with his [or her] own consent, no person shall be hindered in the enjoyment of his freedom of conscience, and for the purpose of this section that freedom includes of thought and of religion, freedom to change his [or her] religion or belief, and freedom, either alone or in community with others, and both in public and in private, to manifest and propagate his [or her] religion or belief in worship, teaching, practice and observance... 


\section{Table 1}

(Continued)

Article 80: $\quad$ Except with his own consent, no person shall be hindered in the enjoyent of his [or her] freedom of assembly and association, that is to say, [the individual's] right to assemble frecly and associate with other persons and in particular to form or belong to trade unions or other associations for the protection of his [or her] interests.

\section{Illustration 3 - North Africa}

\section{Egypt:}

Article 40:

Article 45:

Article 46:

Article 47:

Article 48:

Article 53:

Article 54:

Article 57:
Part Three: Public Freedoms, Rights and Duties (Articles 40-63).

All are equal before the law. They have equal public rights and dutes without discrimination due to sex, ethnic origin, language, religion or creed...

The law shall protect the inviolability of the private life of citizens.

The State shall guarantee the freedom of belief and the freedom of practicing religious rights.

Freedom of opinion shall be guaranteed...

Liberty of the press, printing, publication and mass media shall be guaranteed. Censorship on newspapers shall be forbidden as well as notifying, suspending or canceling them by administrative methods... The right to political asylum shall be guaranteed by the state to every foreigner persecuted for defending the people's interests, human rights, peace or justice. The extradition of political refugees shall be prohibited.

Citizens shall have the right to peaceful and unarmed private assembly, without the need for prior notice...

Any assault on individual freedom or on the inviolability of the private life of citizens and any other public rights and liberties guaranteed by the constitution and the law shall be considered a crime, whose criminal and civil lawsuits is not liable to prescription...

\section{Illustration 4 - Southern Africa}

South Africa: Chapter 2 of the 1996 Constitution: Bill of Rights.

Section 7: This Bill of Rights is a cornerstone of democracy in South Africa. It enshrines the rights of all people in our country and affirms the democratic values of human dignity, equality and freedom...

Section 9(1): Everyone has inherent dignity and the right to have their dignity respected and protected...

Section 11: $\quad$ Everyone has the right to life...

Section 15(1): Everyone has the right to freedom of conscience, religion, thought, belief and opinion...

Section 16(1): Everyone has the right to freedom of expression...

Section 29(1): Everyone has the right to (a) a basic education, including adult basic education.

Section 29(2): Everyone has the right to receive education in the official language or languages of their choice in public educational institution where reasonably practicable... 


\section{Table 1}

(Continued)

\section{Illustration 5 - Francophone Africa (French-speaking Africa)}

Mauritania: Article 10 [Individual Freedom, Rule of Law].

(1) The State shall guarantec to all its citizens public and individual freedoms:

- the freedom to travel and to settle in all parts of the territory of the Republic;

- the freedom of entry to and of exit from the national territory;

- the freedom of opinion and thought;

- the freedom of expression;

- the freedom of association and the freedom to belong to any political or labor organization of one's choice;

- the freedom of commerce and industry; and

- the freedom of intellectual, artistic, and scientific creative effort.

(2) Freedom may be limited only by law.

\section{Illustration 6 - Lussophone Africa (Portuguese speaking Africa)}

Mozambique: Chapter 11. Rights, Duties and Freedoms.

Article 73

(1) All citizens shall have the right and duty to participate in the process of extending and consolidating democracy at all levels of State and society...

Article 74 (1) All citizens shall have the right to freedom of expression and to freedom of the press as well as the right to information.

(2) Freedom of expression, which includes the right to disseminate one's opinion by all legal means, and the right to information, shall not be limited by censorship.

(3) Freedom of the press shall include in particular the freedom of journalistic expression and creativity, access to sources of information, protection of professional independence and confidentiality, and the right to publish newspapers and other publications.

(4) The exercise of the rights and freedoms referred to in this article shall be regulated by law based on the necessary respect for the Constitution, for the dignity of the human person, and for the mandates of foreign policy and national defense.

Article 75 (1) All citizens shall have the right to freedom of assembly within the terms of the law.

Article 76 (1) All citizens shall enjoy freedom of association...

Article 77 (1) All citizens shall have freedom to form and to participate in political parties...

Article 79 (1) All citizens shall have the right to scientific, technical, literary and artistic creativity... 


\section{Table 1}

(Continued)

Article 82

(1) All citizens may contest acts that violate their rights recognized under the constitution and other laws.

Source: Constitution Finder, University of Richmond. http://www.richmond.edu/ jpjones/confinder/

*** The use of "he and his" as recurrent metaphors for both male/female genders in a number of these constitutions suggests that these documents were written (mostly) by men, and that they may reflect Africa's patriarchal society.

The human rights provisions in the Mozambique constitution are extensive probably because of the many years that she fought the Portuguese for independence, and later the civil war that claimed the lives of so many. The need to protect the rights of those who survived these wars remains imperative.

probably the case because constitutional provisions on human rights in the constitutions "consciously" or "tactically" assume that men and women are subsumed in human rights doctrines.

One of the notable exceptions in the continent's "peripheralization" of the rights of women and women's interests in a national constitution (outside the countries under review) could be found in the Ugandan constitution. Besides addressing, in Chapter 4 of the constitution, the central themes of equality and freedom from discrimination; protection of right to life and personal liberty; ... right to a clean and healthy environment, and so on, it specifically deals with the rights of women under Article 33 thus:

- Women shall be accorded full and equal dignity of the person with men.

- The State shall provide the facilities and opportunities necessary to enhance the welfare of women to enable them to realize their full potential and advancement.

- The State shall protect women and their rights, taking into account their unique status and natural maternal functions in society.

- Women shall have the right to equal treatment with men and the right shall include equal opportunities in political, economic and social activities.

- Without prejudice to article 32 of this Constitution, women shall have the right to affirmative action for the purpose of redressing the imbalances created by history, tradition and custom.

- Laws, cultures, customs or traditions which are against the dignity, welfare or interest of women or which undermine their status are prohibited by this Constitution. 
Moreover, the Ugandan constitution provides in Article 51 a Human Rights Commission whose raison d'elre is to address the possible violations of the provisions of human rights contained in the constitution, by an individual, groups, the state and other agencies.

Generally, the measures outlined for the mollification of human rights infringements in Africa through constitutional means are relatively impressive. To be sure, it is one thing to craft the modalities for the resolution of human rights issues in any system, and quite another to practice the principles contained in this document. The problematic dimensions of the latter are borne out in part by the comprehensive report released by the Bureau of Democracy, Human Rights, and Labor United States Department of State. The following sketchy, and yet significant, summaries on human rights report on Egypt and South Africa (examined for the purpose of illustration) are derived from the 6 constructed illustrations. And, they are likely to bring into sharp focus the centrality of the paradoxes and dilemmas that often exist between the implementation of what is written in an African constitution and the actual practice of human rights declarations in a polity itself.

In the analyses that follow, references to relevant articles in Illustrations 1-6 are made. For example, pertinent references as they relate to specific human rights violations will be made in Illustration 3 for Egypt and Illustration 4 for South Africa. In this way, I am able to eschew repetitions of the texts of the article in the constitutions of Egypt and South Africa with which I support the central report for each country since the doctrines are clearly affirmed in the appropriate illustrations.

\section{Summary Report on Human Rights Practices in Two African Countries}

\section{Egypt}

The 1999 U.S. Department of State report on human rights practices revealed that although violent acts by security forces against anti-government organizations lessened somewhat, government security forces continued to perpetuate human rights abuses. Human rights infractions in Egypt are exacerbated by the Emergency Law of 1981, which restricts basic rights. In the guise of fighting terrorists and opposition forces, the security forces have continued to mistreat and torture prisoners, arbitrarily arrest and detain persons, hold detainees in prolonged pretrial detention.

Reports of torture and mistreatment at police stations remain frequent in violation of Article 57 of the constitution (in Illustration 3). Indeed, the Interior Minister, Habib Al-Adly, admitted that such infractions existed, and still exist, and affirmed the government's concern and intention to curb 
repeated violations of the human rights of Egyptians - an act that could promote the regime's political legitimacy. The problem, though, is that such statements are generally made by the government to momentarily mollify and pacify public agitations over human rights transgressions. Saad Eddin Ibrahim, an academic, of the Ibn Khaldun Center for Developmental Studies was arrested by government agents on "trumped up" charges for steering up trouble in the republic by promoting human rights and democracy. This is an example of how government policies sometimes equivocate when it comes to the rights of persons perceived to be a threat to the government and its custodians (Ibrahim 2002; Spencer 2003, p. 57). In fact, generally, the guardians of government often claim that they support human rights instruments in their countries. But such assertions notwithstanding, government agents tend to suppress, intimidate and punish those who stoutly condemn their human rights violations a paradox, indeed! Ibrahim's freedom, to express his views, was abridged by the government of Egypt that claimed that this scholar was a saboteur for advocating an "authentic" democracy and the respect for human rights in this republic. His arrest and trial are in violation of Article 47 of the constitution.

Domestic violence against women remains a thorny issue in Egypt. Although the Government attempts to enforce the 1996 decree banning the practice of female circumcision many families, especially in the rural areas, persist in subjecting their daughters to the traditional practice. Moreover, women and Christians occasionally face discrimination based on Muslim "traditions" and some aspects of the law. Such periodic and unpleasant treatments of women and religious minorities in Egypt are in violation of Article 46 of the constitution.

The abilities of opposition parties to operate freely in the society are sometimes curtailed and impugned by some overzealous government agents who seek to protect their parochial political interest. But such acts are in violation of Articles 54 and 57 of the constitution. The Ministry of Interior often confiscates leaflets and other materials published by Muslim fundamentalists and other critics of the regime. For example, in March 1999 six members of the Tagammu Opposition Party were arrested by security forces following a meeting in Cairo to discuss opposition to a labor legislation that was drafted by the government. They were arrested and charged for possessing publications that were provocative, and that disturbed public order and security. Such detention was in violation of Article 54 of the constitution.

Under the Constitution, Islam is the official state religion and primary source of legislation. Accordingly, religious practices that clash with Islamic law are frowned upon. In most matters of family law, including marriage, 
divorce, alimony, and child custody, religious minorities are inadequately protected by law. Further, in cases of family disputes involving a marriage between a Christian woman, for instance, and a Muslin man, Islamic law prevails. Moreover, the children of such inter-religious marriages must be raised as Muslims. Generally, Muslim women are discouraged from marrying non-Muslim men because of conflicting problems flowing from religious practices and beliefs. These acts are in contravention of Articles 40 and 46 of the constitution (U.S. 1999 Country Reports on Human Rights Practices, February 25, 2000). But is the report any better in South Africa?

\section{South Africa}

Although the report on South Africa was relatively good, the 1999 report, nevertheless, pointed out some areas of concern on human rights issues. It was, however, clear that a number of laws from the apartheid epoch remained in the book. This problem, in the republic, was illustrated in the laws that restricted the publication of information about the police, the national defense forces, prisoners, and mental institutions for fear that they might reveal human rights infractions. Although these laws had not been enforced regularly, human rights groups, and journalists in particular, see these measures as threats to the freedom of the press - acts that violate Section 16(1) of the Bill of Rights (in Illustration 4).

Freedom of religion is not fully practiced in spite of this provision in Section 15(1) of the Bill of Rights. For example, in January 1999, the Government denied MAGO, a group believed to be associated with the radical Islamic-based political group Qibla, a permit to march. This was the case because the government felt that such a demonstration could be violent and threaten the peace. MAGO members, nevertheless, demonstrated in spite of the denial. In response, police arrested several protesters, and fired rubber bullets that killed a member and injured several others. The denial of this group's right to march is in violation of Section $15(1)$ and 16(1) of the Bill of Rights.

Xenophobia remains a major area of human rights transgression in South Africa. The act of violence, against foreigners, especially refugees and asylum seekers in the republic, is extraordinary. Although the government does not sanction such intimidation as a policy, its "reluctance" to curb it issues from the suspicion that some of these refugee seekers were criminals (Shaw 2002, pp. 291-316), and that other foreigners had come into the republic to take jobs away from South African citizens.

Though not approved by the regime, the high rate of violence against women by wife beaters including rape, assault and battery, and domestic violence is phenomenal in the republic. Discrimination against women remains a major problem despite legal and constitutional protections, 
particularly in areas such as wages, extension of credit, and access to land (U.S. 1999 Country Reports on Human Rights Practices, February 25, 2000). Generally, these human rights infractions have traditional and cultural undertones that to some extent represent the paternalistic tendencies that are peculiar in much of Africa. Take, for instance, the impact on Nigeria of the problematic enforcement of Shari'a law in the republic (particularly Northern Nigeria) as it concerns women's rights. Bariya Ibrahim Magazu, a lady who was both pregnant and unmarried claimed in court testimony to have been raped by three men in her village. The denial of the men that no such act took place exculpated them, but the woman's affidavit did not exonerate her. Her punishment was 180 lashes with 100 strokes executed before a crowd just a week after she delivered her child (Afrol News 2002; Okome 2004). The moral of the story is very clear: women are not subjected to the same rights as men when it came to human sexuality in the northern states that practiced this Islamic form of jurisprudence. Indeed, the punishment imposed on, and violation of the human rights of, this and other women in some of the northern states resulted, among other factors, in the cancellation of the Miss World pageant scheduled in Nigeria in 2002.

The above concise reports and analyses on human rights curtailments in Egypt and South Africa are real in these, and other African countries, in spite of the various constitutional provisions intended to protect these rights in the area. To be sure, it is true, also, that sometimes the infractions on individual and group rights are perpetuated by rogue agents of the government who claim to act at the behest of the regime. Often, such agents and agencies violate human rights principles in the society in order to further their individual and group interest/s.

In all, the issues of human rights transgressions are not peculiar to Africa. Indeed, the problems are mondial. Witness, for example, the problematic racial profiling in the United States, and the xenophobic offences unleashed against foreigners in Europe (Udogu 2000, p. 35). The question, then, is why do government agents and others continue to "abuse" the human rights of individuals and groups despite international human rights compacts and national constitutional provisions forbidding such acts?

\section{Universal and Cultural Relativity Debate on Human Rights: A Concise Analysis}

At the heart of the discourse is whether human rights notions are universal in character and applicability or whether they are culturally relative. Put another way, are human rights issues universal or could they be interpreted and applied differently within the framework of the socio-cultural contexts and specificities of different milieus? 
Jack Donnelly (1998, pp. 33-35) argued that human rights are universal norms that derive directly from humanity and thus speak to the best or unselfish aspect of humanity's moral nature. This is borne out by the assumption that human rights are inalienable and relatively absolute in terms of their application and scope. Thus, human rights form and depict a shared human heritage of humankind that transcends cultural relativism. He infers that "the possibility of justifiable modifications, however, must not obscure the fundamental universality of international human rights norms (Donnelly 1998, p. 44)."

Conceptually, the principal of cultural relativity posits that moral codes and social institutions mirror a vast scope of cultural peculiarities and that such variations should be taken seriously in the analysis of human rights issues in the world. This philosophy is grounded on the belief in communal autonomy and right to self-determination, and also suggests that there exists infinite variability in the practice of human rights (Ibhawoh 1999, p. 4).

The theoretical opinions regarding the universality of human rights issue have been the subject of debate among scholars. Argumentatively, academics have discussed the issue from different perspectives. Some have done so from a socio-historical point of view and others from a legal sense. For example, Lone Lindholt and others (1997, p. 26; Ihbawoh 1999, pp. 5-6) have grouped and systematized, as it were, the deliberation on the universality and cultural relativity of human rights under a number of schools of thought according to geographical and cultural demarcations or boundaries. For example, American scholars tend to be more inclined toward a "radical" theory of universalism. Thus, Rhoda Howard (1986, p. 12), one of the foremost scholars in this school, argues with respect to Africa that human rights ought to be universal while admitting, empirically, that cultural variations may affect individual's images or perceptions of human rights. Similarly, the argument has been made that in the theoretical analysis on human rights practices the claims of universality and inalienability of human rights are probable for some specific rights, and invalid for many other rights (Ihbawoh 1999, p. 6).

The centrality of these contentions rests on whether the African concept of human rights should contrast from that of the Western traditions. As the argument goes, some of the Western institutions, cultures, and behavior patterns that were extended to the continent during the colonial epoch were alien to the African cultures. Thus, a number of Africanist scholars who emphasize the cultural relativity of human rights question have argued that the contemporary concept of human rights derives from the Universal Declaration of Human Rights and therefore is not peculiar to "traditional" Africa. Indeed, Issa G. Shivji (1989, p. 10) was blunt when he noted that human rights as a universal concept did not exist in pre-colonial 
Africa. Therefore, "what are usually put forward as African human rights conceptions by its proponents are nothing more than notions of human dignity and worth which existed in all societies." Similarly, Howard noted:

There is no specifically African concept of human rights. The argument for such concept is based on a philosophical confusion of human dignity with human rights, and on an inadequate understanding of structural organization and social changes in African society. Underlying this inadequate understanding, a number of assumptions regarding the meaning of culture are used to buttress the reliance on the assertion of "cultural relativity," in order to argue that the allegedly "Western" concept of human rights cannot be applied to Africa. (Howard, p. 23)

It has been argued elsewhere, however, that theoretical and conceptual debates aside, the fact that African countries embraced human rights instruments within the United Nations, developed its own covenant, The African Charter on Human and Peoples' Rights, and include human rights principles in their constitutions, lend support to the obligation for the universal application of human rights doctrines throughout the continent (Udogu 2001, pp. 87-104).

In a broader context, though, there is a need for scholars to critically examine some of the traditional attitudes of the African peoples and to relate them to human rights issues contained in African constitutions. This approach might help in explicating the conflicts inherent in human rights implementations and probably assist in the provision of solutions. In fact, in his essay on "Human Agency and Democratic Challenges in Africa," Wisdom J. Tettey (2000, pp. 13-49) delved into certain cultural behavior patterns in Africa that tend to impede the development of democracy and a priori respect for human rights. Tettey alluded to the work of Maxwell Owusu who observed that:

Given the pervasive influence (direct and indirect) of the highly resilient indigenous culture or custom and tradition on contemporary African politics and the universal attachment of Africans to their ancestral beliefs and practices, that is the very close implicit relationship between culture and politics, this relationship must obviously be the starting point of any inquiry into the nature and causes of contemporary political development in Africa, not least into the process of democratization, [and human rights issues] and its domestication. (Owusu, 1997, p. 122)

Sometimes, the above characteristics are furthered by the general notion of gerentocratic infallibility on the continent that constitutes one of the most significant impediments to the establishment of democratic and human rights cultures. "The generally accepted view that one needs to always concede to elders in disputes generally curtails free expression and 
stifles the individual's right to hold dissenting opinions. [Moreover,] it becomes difficult after many years of being socialized to kowtow to those in authority, for individuals to suddenly [challenge these authorities even when their views are somewhat anachronistic and represent an antithesis to the practice of the respect of human rights in the polity] (Tettey 2000, pp. 22-23)."

The population of much of Africa, particularly sub-Saharan Africa, is rural and cultural practices in this area are difficult to change. For example, it is difficult to convince local chiefs and elders in the village that female, and for that matter male, circumcision may not only be relatively "dangerous" to the individual who is put through this "ordeal" but could also violate the rights of such a "victim." In fact, refusal to undergo such a practice in some African communities could lead to ostracism no matter how well placed the individual might be in the society or where he or she is domiciled. So, whereas a number of constitutions and laws today may forbid such a practice, it is hardly ever enforced. The argument been posited here is that there exist a number of traditional social and religious customs that make it difficult for governments to enforce human rights laws in Africa and elsewhere. But, this does not imply that the instrumentalities for improving human rights practices in Africa cannot be explored because of such customs. To this end, the proceeding discussion will focus on some ways that African countries might improve on their human rights record.

\section{Some Recommendations for Solving Human Rights Issues in Africa}

It is worth noting that in order to promote human rights provisions contained in national constitutions, some African states have held conferences to publicly declare their position and support for the respect of the fundamental human rights of their citizens. These convocations underscore the symbiosis between human rights and democracy. Indeed, such was the result of the International Symposium held by Francophone African Countries on November 1-3, 2000, in Bamako, Mali. The communiqué, which was submitted to the Fifty-fifth session of the United Nations General Assembly as agenda items 39 and 114, was distributed on January 10, 2001 (see United Nations General Assembly doc. A/55/731, pp. 1-9).

The Bamako Declaration on the Practices of Democracy, Rights and Freedoms in the French-speaking African countries stated under section D of the document that in order to promote full respect for human rights and internalize democratic culture the following practices were imperative for African states:

- To develop a spirit of tolerance and promote democratic culture in all its dimensions, so as to foster awareness among public officials, 
all participants in political life and all citizens, through education and training, of the ethical requirements of democracy and human rights...

- To ratify the principal international and regional human rights instruments, fulfill and perfect the commitments undertaken thereby, ensure their full implementation and train all those in charge of their proper enforcement...

- To create, promote and strengthen national consultative and nonconsultative human rights bodies, support the establishment of human rights structures in national administrations and support actions in defense of human rights;

- To take the appropriate steps to grant members of minority groups, whether they be ethnic, philosophical, religious or linguistic groups, freedom to practice or not to practice a religion, the right to speak their own language and the right to have their cultural life... (United Nations General Assembly doc. A/55/731, p. 6)

Moreover, the groundswell in the literature on human rights in recent years attests to the significance placed on the quest for improving human rights applications in the 21 st century. Indeed, many scholars and practitioners concerned with human rights problems have labored hard to bring the question of human rights infringements in different polities to the fore. Unfortunately, many states in the continent have been too weak due to ethnic clashes, civil wars and apathy to implement human rights principles contained in their constitutions. Also, their lack of enthusiasm to enforce human rights dogmas may issue from the apprehension that such observance might militate against their regime's interests - particularly the political survival of the custodians of power.

The celebrations of the 50th anniversary of the signing of the 1948 Universal Declaration of Human Rights at many forums in the late $1990 \mathrm{~s}$ underscored the significance of human rights issues in our contemporary global village, and the possible politico-social stability that human rights observance could engender in many societies. The "new globalization" suggests that bold and new strategies are needed in the quest for attaining universal realization of the respect for human rights. It is within this broader context that it has been suggested that in order to further the universality of human rights applications the following proposals, among others, should serve as important steps in the process of improving human rights application:

- Every country needs to strengthen its social arrangements for securing human rights freedoms - with norms, institutions, legal frameworks and an enabling economic environment. Legislation alone is not enough. 
- The fulfillment of all human rights requires democracy that is inclusive - protecting the rights of minorities, providing separation of powers and ensuring public accountability. Elections alone are not enough.

- Poverty eradication is not only a development goal - it is a central challenge for human rights in the 21 st century.

- Achieving all rights for all people in all countries in the 21 st century will require action and commitment from the major groups in every society - NGOs, media and businesses, local as well as national government, parliamentarians and other opinion leaders... (Human Development Report 2000, pp. 6-13).

Whereas the foregoing dimensions calling for actions to tackle human rights questions globally are self-explanatory, and may serve as rallying cries for human rights NGOs, some African states have already articulated opinions that are likely to accomplish similar objectives in the continent. In this regard, I am referring to the comprehensive Bamako Declaration in which Francophone African countries reaffirmed their belief in the principles of human rights and democracy based on recognition of the inalienable nature of the dignity and equal value of all human beings within the rule of law.

In the quest to further the respect for human rights in Africa, a number of countries in Africa declared, among other proclamations, the interlacement of human rights practices, democracy and the rule of law in promoting political stability and peaceful coexistence in Africa, thus:

That democracy, as the political framework for the rule of law and the protection of human rights, is the system of government that best promotes long-term stability and legal security; thanks to the climate of freedom [and lasting peace] that it creates... (United Nations General Assembly doc. A/55/731, p. 4)

\section{Conclusion}

The saliency of the violations of human rights of the African peoples is a problematic one. Indeed, because human rights infractions are rampant and serious in much of Africa most countries chose to address the issue in their national constitutions. This essay has, inter alia, attempted to highlight and summarize human rights provisions contained in the constitution of 6 countries, drawn from different regions of the continent and to examine the reports in two countries, namely, Egypt and the Republic of South Africa. The quest to address the question of human rights violations may tax the [social and intellectual] wits of the numerous non-governmental organizations (NGOs) charged with identifying and combating the non-compliance of human rights provisions by individuals, 
groups and governments. Nevertheless, it is encouraging that governments in Africa are relatively amenable to the efforts of NGOs. Also, the creation of the African Commission on Human and Peoples' Rights whose raison d'etre is to safeguard the human rights provisions contained in the African Charter on Human and Peoples' Rights (ACHPR) suggests the importance placed on human rights issues in the continent by African countries.

But the above approaches would be hollow, and indeed useless, if the necessary modalities for successfully implementing the aims and objectives contained in national constitutions, ACHPR, international human rights instruments and the Bamako Declaration itself are not put in place. One such instrumentality is education.

Although the various human rights provisions are intended to address human rights issues nationally and universally, it would appear that only members of the informed public that constitute less than 50 percent (Human Development Report 2000, pp. 194-197) in the African situation are more likely attuned to these rights and freedoms. Put another way, attempts to promote the human rights of Africans may be worthless if a majority of those whom these rights are guaranteed are unaware that the protections exist Aka and Browne 1999, pp. 432-433). In this regard, the declaration of January 1995 to January 2005 as the UN Decade for Human Rights Education is commendable (Aka and Browne 1999, p. 439). But time is about to run out. And, indeed, citizens in African states and elsewhere need such an education on human rights and their practices in order for individuals and groups (in cities, particularly bidonvilles, and villages) to protect the rights and freedoms contained in all international and national human rights compacts and constitutions. In this way, African governments might become more relevant to their citizens especially at this crucial juncture of the continent's democratic and economic renaissance.

\section{References}

African Charter on Human and Peoples' Rights

1982 OAU Secretariat, Division of Press and Information, Addis Ababa, Ethiopin.

Afrol News

2002 "Increased Pressure on Nigerian Shari'a Death Sentence." http://www.afrol. com/News2002/nig003 sharia woman3.htm

AKA, PHILliP C. AND Gloria J. BROWNE

1999 "Education, Human Rights, and the Post Cold War Era," New York Law Schwol Joumal of Human Rights, Vol. XV, Part 3, pp. 421-448.

ANDREWS, WILLLAM G. (ED.)

1963 Constitutions and Constitutionalism. Princeton, NJ: D. VanNostrand, Inc.

DONNELLY, JACK

1998 International Human Rights. Boulder, CO: Westview Press. 
HOWARD, RHODA

1986 Human Rights in Commonwealth Africa. New Jersey: Rowan \& Littlefield.

Human Development Repart 2000

2000 New York: Oxford University Press.

Human Rights AND DEVElopment IN AFrica: Establishing the RULE OF LAW

1999a 26 Annual Symposium, University of Illinois, Urbana-Champaign, July 8-10, 1999.

IBHAWOH, BONNY

1999 "Cultural Relativism and Human Rights: Reconsidering the Africanist Discourse," Human Rights and Development in Africa. Establishing the Rule of Law, $26^{\text {th }}$ Annual Symposium, University of Illinois, Urbana-Champaign, July 8-10.

IBRAHIM, SAAD E.

2002 Democracy-Egypt. http://www.democracy-egypt.org/

IHONVBERE, JULIUS O.

2000 Towards a New Constitutionalism in Africa. Centre for Democracy and Development, London, EN.

LANE, JAN-ERIK

1996 Constitutions and Political Theory. Manchester, England: Manchester University Press.

LINDHOLT, LONE

1997 Questioning the Universality of Human Rights. Copenhagen, Norway.

LUTZ, DONALD S.

1994 "Toward a Theory of Constitutional Amendments." American Political Science Review, Vol. 88, No. 2, pp. 355-370.

MBAKU, JOHN M,

1996 "Effective Constitutional Discourse as an Important First Step to Democratization in Africa." Joumal of Asian and African Studies, Vol. 31, Nos. 1-2, pp. 39-50.

OKOME, MojubaOlu O.

2004 "The Nature of the Nigerian State, Gender Politics, and the Empowerment of Women in the $21^{\mathrm{st}}$ Century," in UDOGU, E. IKE (ed.), Nigerian in the $21^{\text {st }}$ Century: Strategies for Political Stability and Peaceful Coexistence (forthcoming).

OWusU, MAXWELL

1997 "Domesticating Democracy: Culture, Civil Society, and Constitutionalism in Africa." Comparative Studies in Saciety and History, Vol. 39, No. 1, pp. 120-153.

PLANO, JACK C. AND GREENBERG, MILTON

1985 The American Political Dictionary. Holt, New York: Rinehart and Winston.

SHAW, MARK

2002 "West African Criminal Network in South and Southern Africa." African Affairs, Vol. 101, No. 404, pp. 291-316.

SIGMUND, PAUL

1979 "Carl Fricdrich's Contribution to the Theory of ConstitutionalismComparative Government," in J. Ronald Pennock and John W. Chapman (eds.), Constitutionalism. NY: New York University Press.

SPENCER, WILLIAM

2003 Global Studies: The Middle East, Guilford, CT.: McGraw-Hill Companies. 
THE SOUTHERN AFrican HUMAN Rights READER: TOWARdS Creating A Sustainable Culture of Human Rights

1998 Compiled by B.F. Bankic, C. Marias and J.T. Namiscb. Namibia, Windhock: Gamsberg Macmillan.

TETTEY, WISDOM J.

2000 "Human Agency and Democratic Challenges in Africa." Africa Quarlerly, Vol. 40, No, 2, pp. 13-49.

UDOGU, E. IKE

2001 "Human Rights and Minorities in Africa: A Theoretical and Conceptual Overview." Joumal of Third World Studies, Vol. 18, No. 1, pp. 87-104.

2000 "An Examination of Minority Groups and Human Rights Issues in Europe and Africa". The Joumal of Political Science, Vol. 28, pp. 21-43.

1997 a "Military Politics and Constitutional Discourse: Towards Nigeria's Forthcoming Republic". Makerere Political Science Review, Vol. 1, No. 1, pp. 1-21.

$1997 \mathrm{~b}$ (ed.) Democracy and Democratization in Africa: Toward the $21^{\text {t }}$ Centum. Leiden, the Netherlands.: E. J. Brill Publishers.

United Nations General Assembly

2001 doc. A/55/731 of January 10,2001 . Bamako Declaration is annexed to the letter dated 22 November 2000 from the Permanent Representative of Mali to the United Nations addressed to the Secretary-General. It was submitted to the Fifty-fifth session as agenda items 39 and 114 .

U.S. 1999 Country Reports on Human Rights Practices, February 25

2000 http://www.statc.gov/www/global/human_rights/1999_hrp_report/ egypt.html

http://www.state.gov/www/global/human_rights/1999_hrp_report/ southafr.html

U.S. 1997 Country Reports on Human Rights Practices, January 30

1997 http://www.state.gov/www/global/human_rights/1996_hrp_report/ cameroon.html

http://www.state.gov/www/global/human_rights/1996_hrp_report/ kenya.huml 
Copyright $@ 2003$ EBSCO Publishing 